O. N. Starokozhko, Cand. Sc. (Pedag.), Assoc. Prof., orcid.org/0000-0003-3793-9655,

V. V. Kryzhko, Cand. Sc. (Pedag.), Prof., orcid.org/0000-0002-7144-7892,

V. I. Zhygyr, Dr. Sc. (Pedag.), Prof., orcid.org /0000-0002-1501-905X
Berdiansk state pedagogical university, Berdiansk, Ukraine, e-mail: starokogko@ukr.net

\title{
THE TRANSVERSAL CHARACTER OF POLYPARADIGMAL EDUCATIONAL SPACE
}

Purpose. Research on the main transversal characteristics of the polyparadigmal educational space.

Methodology. The scientific discourse of domestic and foreign scientists as for the given problem; historiographic method of continuum of educational space's scientific concepts; technologies of the reflexive analysis of scientific community's achievements and our own experience in the field of management of social environment and its structural systems; modeling of the process of transversal connections; methods of mathematical analysis for establishing real patterns of the transversal correlation or concepts conflict of polyparadigmal educational environment.

Findings. It is found that transversal character of the polyparadigmal educational environment is its implicit methodology, which enriches it with new "composite" forms. This creates conditions under which the emergent factors and new phenomena arise in the field of educational paradigms. A scheme of author's technology of the analysis of emergent zones of transversal interaction of educational paradigms is developed. The internal logics of paradigmality are briefly disclosed in the author's scheme of transversal interaction of domestic polyparadigmal educational space. Content components of transversal interaction of the educational space's paradigm are defined. The approbation of results for three years is carried out in the educational process of training of educational managers according to specialty "Management of educational establishment".

Originality. For the first time, the concept "polyparadigmal educational space" has been proposed and introduced into scientific discourse; factors of dual transversal interaction of the educational paradigm have been defined and the scheme of transversal interaction of educational paradigms has been developed.

Practical value. The use of results raises the scientific discourse on the problem of methodology of polyparadigmality and transversality of the educational space. The developed technological schemes and models can be used in further scientific research and educational process in preparation of educational managers.

Keywords: polyparadigmal educational space, transversal mind, transversal skills, reflexive paradigm, competence paradigm, synergetic paradigm, axiological paradigm, guiding paradigm

Introduction. The author's reflexion of the educational space of Ukraine made it possible to reveal a rather complex polyparadigmal situation of this social environment. We explain this by palliative nature of high education reform and management of it; adopting the EHEA standards and values; fluctuation influence of internal educational policy and state management; growing scientific and research needs and resources of the highly qualified subjects of the educational space.

The educational spaces (civilizations) are defined by the diversified internal structure which is determined by the needs of the society and dominant educational (pedagogical) ideas, concepts and paradigms.

The second third of the $20^{\text {th }}$ century was marked by intensive introduction of scientific paradigms as for organization of educational environment of Ukraine. There was a dialectical change of such scientific concepts: algorithmization of educational activity, structural and logical preparation of didactic phenomena, activity approach, systematic approach, axiological approach, personality-oriented approach, competence approach, synergetic approach. At the same time none of these paradigms existed by itself because this is connected not only with professional and organizational processes but also with mentality of participants of the educational process and needs of society. Paradigms of the scientific space exist in conditions of constant connections, interconnections and interdependence, that is the subject of transversality. That is why we have the right to speak about the polyparadigmal and transversal nature of the national educational environment.

We have found that the main research on the problem of paradigmality of the educational space has, in general, descriptive character. This approach does not express the polyfunctionality of the phenomenon polyparadigmality by the

(c) Starokozhko O. N., Kryzhko V.V., Zhygyr V. I., 2020 complex transformation of "traditional" educational effect, the impact; its usage leads researchers to understand the rapid exhaustion of the problem (dead corner situation). To prevent this we turned to the resources of perspective transversal approach in socio-humanitarian sciences. In our opinion, transversality gives opportunity to express the potential and expected result of each of the paradigms which create a conceptual scientific domain of the educational space. Moreover, in our research, we strengthen the role of methodological modeling of multidimensionality of pedagogical, didactic, psychological and mental structures of each paradigm and emergent phenomena (phenomena) in the zones of their cooperation.

Literature review. The researchers of paradigmality (G. Kornetov， S. Ladyzhets，V. Ogneviuk，M. Romanenko, O. Subeto, S. Klepko, V. Kryzhko, O. Matis, O. Prikot, N. Sobol, O. Stankova, O. Starokozhko, V. Shpak and others).

The coexistence of paradigms, especially humanitarian, allows to make a conclusion that struggle and displacement of paradigm is not so widespread as T. Kuhn supposed, since paradigms, in general, have their own cultural and cognitive niches. As a result of the analysis, formulated principle of polyparadigmality in pedagogy is characterized by the following statements:

- admissibility of coexistence of several methodological systems, within which integrated and complete models of the educational process, expressed in the form of pedagogical theories, technologies and educational systems' models are constructed;

- use of polyparadigmal approaches in the mission of socialization and personality's creative life - the subject of education;

- introduction of the resources of situational paradigms of the educational space in ideological, methodological and cognitive levels;

- situational choice of scientific paradigms is defined by intellectual, motivational and subject-professional characteristics of a teacher; 
- transversal combination of different paradigm elements within the framework of certain methodology and technology of education.

The founder of theories of scientific revolutions T. Kuhn predicted the existence of the subject paradigms in the middle of each paradigm, each of which has its own specific set of ideas about purposes, content and processes of education and teaching. Paradigms do not always change one another. Sometimes they successfully co-exist and complement each other (axiological competence) for a certain period of time. The science of pedagogy is at the "preparadigmal stage", since the presence of many equal paradigms, according to Kuhn, is equivalent to absence of paradigm and is typical for "early stage".

Unsolved aspects of the problem. We have defined that scientific discourse as for methodology of transversal reflexion of polyparadigmal educational space has not formed yet, so we have determined a number of relevant problems:

- to define and substantiate the concept of polyparadigmality of educational space in the context of the phenomenon of its transversality;

- to outline the social and professional zones of conceptual action of scientific paradigms which are supported by the educational community at present time;

- to develop the author's technology of modeling emergent formations in the educational polyparadigmal space;

- to develop the elementary technologies of determining the effective transversal synergies of the educational space to the level of management implementation.

\section{Purpose.}

1. To activate the scientific discourse on the problem of polyparadigmality of the educational space.

2. To formulate and introduce the author's definition of the notion "polyparadigmal educational space" into the discourse and scientific use.

3. To identify the content components and emergent zones of scientific paradigms of the domestic educational space.

4. To work out the scheme of transversality of main paradigm components of modern educational space.

5. To establish the transversal character and conditionality of effective correlation or conflict of scientific paradigms and determine the ranks of these processes.

Methods. We have used the resources of scientific discourse of domestic and foreign scientists as for the given problem; historiographic method of the continuum of scientific concepts of the domestic educational space; our research uses technologies of reflexive analysis of the scientific community's achievements and our own experience in the field of management of social environment and its structural systems; scientific discourse for expressing different approaches and visions of the given problem; isolation of the important fragment and sector of the problem for processing and further projecting of the results on the system as a whole; modeling processes of transversal connections; methods of mathematical analysis for establishing real patterns of transversal correlation or conflict of concepts of polyparadigmal educational environment.

Results. Pedagogy uses borrowed scientific terminology in the field of psychology, sociology, management and biology. Therefore, it is not surprising that the concept of transversality is taken from mathematical sciences to pedagogy. In most cases, researchers used one of the main mechanisms of transversality - "the transversal line" - diagonal crossing of the lattice of horizontal and vertical coordinates, a zigzag which interrupts the chain of monotonic changes. We pretend to introduction of not only the "transversal line" but also other methodological approaches which are used in other fields of research.

For further research, the postulate of the French philosopher and psychoanalyst F. Guattari is important according to which constant transversal analysis destroys both horizontal and vertical structures of the system, phenomena and gener- ates transitional objects (in the theory of systems - emergent zones, according to G. Schedrovitsky - "centaur systems"), which self-correct the purpose of the subject group. Ontologically, transversality appears as an intersection and even overlay of different fields of subjectivity of the educational space. The use of the definition of "imposition" by F. Gvattari opens for us the space of the author's methodological research of paradigmality. Challenges of education of the $21^{s t}$ century are reproduced in Jacques Dolor's report (1996) and Rome club's report "Come on!" (2017). The authors talk about the perniciousness of the transition "from consideration of reality as a whole to dividing it into many small fragments". The relevant is cultivation of the integral thinking but not restrict of the analytical thinking. A. Einstein and L. Infeld wrote that "All existence ideas in science were born in dramatic conflict between reality and our ways of understanding it".

Goethe J. remarked: "They say that there is truth between two opposite thoughts". In no case! Between them lies the problem...".

The domestic researcher of the phenomenon of transversality of the educational space L. Gorbunova emphasizes that art of the innovative thinking is the art of life which provides not only the correct using of logics, rules of deduction and induction, but also the art of argumentation, the ability to conduct open and constructive dialogue in which the new senses and knowledge configuration are born. Our plural reality, as L. Gorbunova emphasizes, requires transitions between different systems of meanings and constellations of rationalities. This can be realized in the complex transversal thinking. It provides what is needed for after-postmodern forms of life: overcoming closed borders, transition from one system to another, simultaneously taking into account multidirectional efforts and skills to look beyond the paradigmal partitions [1].

Penetrating in the essence of the problem, reviling the obvious and unknown, transversal thinking goes beyond the discipline, considers the interconnections between different aspects of the problem and takes into account different views and opinions. Recognition of implicit entanglements and explicit transitions helps to avoid despotism and repression in thinking and anarchy because thinking in transversal mood overcomes positions of absolute heterogeneity and incommensurability. The notion of complex thinking and transversal mind has considerably heuristic potential in modern conditions of existing of different positions [1]. M. Kuzmin noted that one of the managerial problems in the society whose mentality is common but heterogeneous can be absence of conceptual continuality of management, its discreteness, which is defined by following factors. First, it is inability to disclose the interconnection and interdependence of the problem of mental heterogeneity. Second, it is reactivity in response to the demands of different subcultural groups. In accordance with the purposes of the research, we propose a scheme of the authors' technology of the analysis of emergent zones in the transversal interaction of educational paradigms. We used the principle of "superimposition" by F. Guattari and Vienna rings technology.

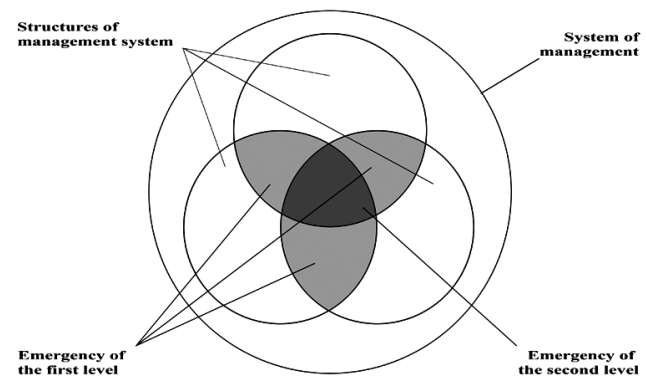

Fig. 1. Graphical model of emergence of zones of transversal interaction of educational paradigms 
In the diagram we can visualize the phenomenon of genesis of emergent zones of different level under conditions of transversal interaction. At the same time we have made sure that the larger the number of paradigms in the educational space is and longer the time of their interaction is, the more expressed and demanded their emergent results become. For the discourse of transversal character of the polyparadigmality of the educational space and its management, we have defined the key concepts of transversality which actually form this phenomenon and create the landscape of the educational space. Philosopher Rene Descartes noted: "Define the meaning of words and you will save humanity from half of its mistakes".

According to the character of the research, these concepts are: transversal mind", "lateral thinking", "transversal reflection", "transversal competences", and "transversals".

In Welsh's view, mind, unlike rationality, is not an ability to provide the first principles of some primary order. He proposes some spheres of consciousness and forms of rationality. It is not something static and principle-oriented. On the contrary, it is dynamic and its activity is revealed in transitions. In this sense Welsh says about "transversal mind" [1]. The notion "transversal mind" has not found its hermeneutical solution yet and it is interpreted in many variants. German philosopher Welsh describes it as a leitmotif of the new thinking, saying that transversality becomes a "focus of reflexion" in conditions when multiplicity becomes the entity and when it is necessary to identify not only the plurality but also connections. According to V.Welsh, transversality is a form of life but not a form of reflection. Transversal mind is not a new mind but new understanding of the mind. Welsh persistently demands from the transversal mind to reconstruct any relation between divergent paradigms. The use of transversal rationality, in his opinion, is caused by the coexistence of different paradigms and conceptions, as different forms of connections which can realize the educational rationality.

"Today, we consider the mind - from the positions of plurality - as the ability to combine forms of rationality and to enable transitions between them". The transversal mind is used, according to Welsh, when the ordinary, subject-oriented mind is not sufficient to express certain specific issues.

So, we have defined that transversal mind is a mental substance of paradigmal groups of the educational space. The lateral thinking is a tool for realization of this substance in its multifaceted nature (E. Bono, L. Gorbunova, A. Patrushev). It is specific information processing directed to changing of the existing stereotype model of perception of reality, creating new alternative approaches to solving the certain problem [2]. Synonymous for this term are effective, productive, non-standard and non-leniar thinking. The main purpose of lateral thinking, according to E. Bono, is generating new ideas and moving away from old fixed stereotypes and ideas, making changes but not searching the evidence, achieving the heuristic moment (when unlikely direction of thought leads to a new, more effective idea). The main tasks of the lateral thinking, in his opinion, are follows: to come not so much to the right as to the effective solution of the problem; to get rid of cliché models, rebuild stereotyped schemes. E. Bono determined the main principles of lateral thinking: 1) awareness of ideas which prevail and are stereotyped; 2 ) search of different approaches to phenomena and problems; 3) release from the rigid control of logical thinking; 4) use of case; 5) understanding that any point of view on something is just one of many possible points of view; 6) postponement of evaluation, judgment; 7) generation of new approaches.

During the study we have identified significant features of the "affinity" of ideas of lateral and scenario thinking.

Transversal management is able to "rise above the versions" of value hierarchies and historical memory. In this case it will be not passive tolerance but active use of specific mental potential of individual sociocultural groups.
We agree with M. Kuzmin's opinion that transversal management in mentally heterogeneous society is able to provide stability in it not only by declaring consent but also by rational procedures which include in itself taking into consideration the diversity of interests and mental and cultural potential of certain groups which are the part of society, anticipation of consequence of managerial ideas in plural mental environment, analysis and prevention of possible conflicts. Transversal skills are multipurpose skills, which can be applied and used in a great number of different roles in the sphere of $\mathrm{Na}$ tional framework of qualifications and mental requirements of European civilization. Transversal skills and abilities in terms of European educational space are understood as corresponding to kinds of activity and professions different from those in which any person is or has ever been engaged. In a broader sense, these are those skills and abilities which have been obtained in one context or for solving one task or problem and can be used in another context [3]. N. Sobol has defined five main groups of "transversal skills and abilities" (competencies) - technical, analytical, organizational, interpersonal interaction and self-development [4].

In modern sociocultural conditions the necessity is actualized to expand the subject-oriented and special competences of the teacher and manager of education by means of the system of so-called transversal competencies. These competences are universal or essential; they are based on generalization of knowledge and skills, abilities and relations. Possession of transversal competences allows being situationally creative; modeling in the educational space the democratic processes and processes of participation in them of educational subjects, based on respect of human rights, human dignity, adoption of divergent vision of problems; being successful in intercultural dialogue. Formation of these transversal competences of the teacher and manager will develop educational subjects' skills necessary for common life in democratic society.

The development of transversal competences can be provided, first, through "learning by action", which allows creating in the educational process and involving subjects to solving of problem situations, which model social problems of life in society. At the same time these competences cannot be formed with the help of "individual teaching". In pedagogical education and advanced training should be strengthened by socalled collective strategy of teaching and learning, which includes teaching in collaboration, methods of work in team, collective (group) methods. This strategy is more effective for forming of social, cultural, ethnic, political and other knowledge and skills which are in the basis of transversal competences [5]. In our research we take the view that transversal system of education is the system of education with functions of educational environment and connections, which intersect and change their configuration, creating not linear chain but network clusters of different scale developed for professional improvement [6]. We consider it necessary to outline briefly the content of paradigms of the domestic educational space.

Competence paradigm (the $90 \mathrm{~s}$ of the $20^{\text {th }}$ century). Based on definitions of scientists (V. Alfimov, T. Baybar, O. Babenko, N. Bibik, O. Vashulenko, A. Grabovoy, I. Gudzik, I.Zimnyaya, T. Isaeva, N. Koval, O. Lokshina, O. Onoprienko, O. Ovcharuk, I. Ovchinnikova, K. Ponomareva, O. Prischepa, O. Pometun and others) we can generalize, agreeing with G. Selevko's opinion that competence paradigm in education means gradual reorientation of dominant educational paradigm with prevailing knowledge translation, forming skills, creating conditions of mastering the competences which denote potential, ability of graduate to survive and sustainable life in conditions of modern multi-aspect social and political, market and economic, informational and communicative saturation of space.

The main conditions for reforming the system of education on the basis of competence paradigm are optimization of the content of education, developed on the competence base; in- 
troduction of personality-oriented approach to organization of educational process, on the basis of which it is possible to take into account professional needs and abilities of subjects, stimulate their desire to mastering the socially and professionally important competences, to seek to realize the individual trajectory of the development (social lift).

Axiological paradigm (the 70s of the $20^{\text {th }}$ century - until now). (I.Zyazun, I. Bekh, N. Tkacheva, N. Kravchenko, V. Kryzhko, D. Dzvinchuk). Axiological bases have become the property of philosophy of education, educology, state management and pedagogical management.

We understand the axiological paradigm as a mechanism of constituting a person as the highest value of being; development and introduction of philosophical, social and sectoral moral and legal schemes of guarantees of inevitability of human value under any circumstances.

Reflexive paradigm (the 80 s of the $20^{\text {th }}$ century - until now). The key ideas of reflexive paradigm are methodology of system, activity, axiological, competence and other approaches. This paradigm is cross-cutting, pervading any conception of the educational space and is present everywhere. The resources of the reflexive paradigm are inexhaustible by their nature. They arise in consciousness, subconscious of the person, participant of the managerial process and they have both rational and irrational as suited the situation. The importance of reflection in the educational process is due to the potential of its influence on the process of self-education and self-development. Being included into the structure of pedagogical interaction, reflection determines the personal orientation of education, promotes its individualization and the fullest disclosure of the personal thinking potential of participants of the educational process.

Synergetic paradigm (the $21^{s t}$ century). Scientists B. Belousov, M. Danilov, O.Zhabotinsky, T. Illina, F. Kirilev, N. Kuzmina, Yu. Klimontovich, G. Nikilis and others have made a significant contribution to the scientific realization of the systematic approach. The founders of synergetics $-G$. Haken and I. Prigozhin insisted on the legitimacy and necessity of using the new science methodology to the analysis of processes of the development of the most complex class of open, non-linear, dynamic systems - sociocultural, since the very existence is their development. According to S. Vitvitska, the synergetic approach reflects the interdisciplinary analysis of scientific ideas, methods and models of system behavior, revealing their potential in thinking about the world and man. In this context, in the process of studying the higher school pedagogy the problems of interdisciplinary dialogue are considered. Peculiarities of social, cognitive and communicative situations are identified and compared with scientific points of view [7].

We consider synergetic paradigm as "relatively rigid framework of methodological principles", which is used now in the reforming of educational systems, in particular in Ukraine (Encyclopedia of Education edited by V. Kremen, 2008).

The synergetic paradigm has revealed new dialectic principles of interaction of opposite beginnings such as: ordering and chaos, constancy and variability, predictability and unpredictability of future, good and evil and others. The synergetics has revealed two main forms of the development of complex systems - bifurcation and evolution; in the latter, bifurcation liquidation only certain elements of systems is realized while saving those positive features which will play the progressive role in the future. On the basis of synergetic paradigm, as is noted in the Encyclopedia of Education (2008), it is possible to optimize the solution of the main task of the modern education, forming of personality which could better combine individual interests with all general public interests. However, although synergetic ideas are increasingly spread in the modern and educational space, they have not been adopted by the UNESCO yet (it has already been noted that it has recognized the absence of the educational concepts which would be up to date), not by leaders of science and education of any country.
The guiding paradigm. There is a new approach to defining the character of these problems and controversies. They are non-paradigmal. The sources of non-paradigmal problems are: obscurity, ambiguity, lack of knowledge, groundlessness, inconsistency of scientific position, inability to explain the phenomenon, phenomenon of the process. The innovative non-traditional ways of educational reality's cognition which are not included into conventional conceptual schemes, problem situations and standards of their solving are non-paradigmal. They require new approaches and methods of scientific search. The guidance in education is a creative extraparadigmal activity of the subject (subjects) of the educational system to expand its theoretical and applied field on the basis of unique author's vision of conscious perspectives which lie beyond the existing normative reality [8].

When selecting components which are included in the "new" paradigm of the educational space we are guided by the following criteria: 1) the selected component must be present in all paradigms; 2) the system connection between components must be traced quite accurately as for educational environment; 3 ) the component must be representative and reflect the specifics of the axiological paradigm in a necessary manner; 4) some components of the new paradigm can nominally correspond to the parts of disciplinary matrix but they cannot be a direct analogy of the latter; 5) the components must have specific connotations due to the peculiarity of the educational space.

The new paradigm of education should be oriented to the forming of the needs in continuous acquisition and updating of knowledge in all subjects of the educational process, improvement of skills and abilities, their conscious fixing and transformation in competence - a set of interrelated qualities of personality: knowledge, skills, abilities, value orientation required by an

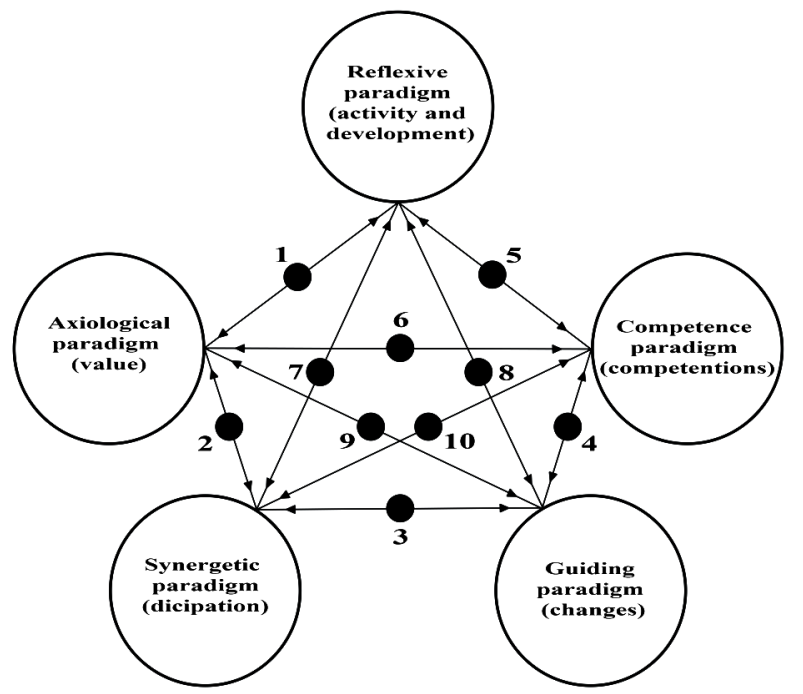

Fig. 2. Transversality of the main components of paradigms of the educational space components of transversal interaction of educational space paradigms.

1. Evaluation of values for transformations.

2. Values adaptability in the period of social and transformational turbulence.

3. Irrational nature of structural changes and content of the educational space.

4. Phenomenal character of solving the mission of educational space changes.

5. Expert and evaluative status of influence actions.

6. Moral and cautionary character of influence mission on the educational space.

7. Non-entropy nature of structural changes of the educational space.

8. Creating new states and organizational forms of the educational space.

9. Providing polymorphism of changes in the educational space. 
individual for creative, productive interaction with other people, with specific objects and processes of the surrounding world.

Here is the author's definition of "polyparadigmal educational space" - a mentally, socially and scientifically defined system of educational ideas, concepts, phenomena, visions, structures and institutions, activity of which is based on the appropriate using of the potential and resources of various paradigmal visions of the progressive development.

Polyparadigmality provides the existence of various scientific and organizational and structural models of modern education and its management.

During the research we have developed a scheme of transversal interaction of the domestic polyparadigmal educational space (Fig. 2).

Strengthening the social responsibility of the educational space management.
The analysis of this scheme allowed us to define the content components of paradigm and factors of emergency of transversal interparadigmal influence of results (Table 1).

The problems of concerted "existence" and conflicts (contradictions) of scientific paradigms in the space of higher education of Ukraine are included in the tasks of our research work. For this purpose, we used the research studies of professional groups of scientists of Berdiansk State Pedagogical University, Melitopol State Pedagogical University named after B. Khmelnytsky, Luhansk State Pedagogical University named after T. Shevchenko, Zaporizhzhia National University and Kirovohrad State Pedagogical University named after V. Vynnychenko. The methodological and paradigmatic orientations of their scientific publications were analyzed. We analyzed scientific works by V.Kipenya, O.Savchenko, V. Ogneviuk, T. Desyatova，N.Tkacheva，V. Grineva，N. Gavrish，O. Pla-

Factors of dual transversal interaction of educational paradigms

\begin{tabular}{|c|c|c|c|}
\hline No & $\begin{array}{l}\text { Duality of } \\
\text { paradigms }\end{array}$ & Content component of the paradigm & Factors of emergency of transversal influence \\
\hline 1. & $\begin{array}{l}\text { Reflexive - } \\
\text { Axiological }\end{array}$ & $\begin{array}{l}\text { Target activity and development. } \\
\text { Moral purpose of management }\end{array}$ & $\begin{array}{l}\text { The choice of effective management strategy and providing of the } \\
\text { humanity of its realization }\end{array}$ \\
\hline 2. & $\begin{array}{l}\text { Axiological - } \\
\text { Reflexive }\end{array}$ & $\begin{array}{l}\text { Moral purpose of management } \\
\text { Target activity and development. }\end{array}$ & $\begin{array}{l}\text { Monitoring of values of educational management with the aim of their } \\
\text { stabilization or managed transformation }\end{array}$ \\
\hline 3. & $\begin{array}{l}\text { Reflexive - } \\
\text { Guiding }\end{array}$ & $\begin{array}{l}\text { Target activity and development. } \\
\text { Generation and implementation of changes }\end{array}$ & $\begin{array}{l}\text { Strategies of educational policy and management as for providing } \\
\text { graduality and inevitability of managerial changes of educational } \\
\text { paradigm }\end{array}$ \\
\hline 4. & $\begin{array}{l}\text { Guiding - } \\
\text { Reflexive }\end{array}$ & $\begin{array}{l}\text { Generation and implementation of changes } \\
\text { Target activity and development }\end{array}$ & $\begin{array}{l}\text { Social and legal motivation of subjects of educational paradigm } \\
\text { regarding the choice of new strategies of the development }\end{array}$ \\
\hline 5. & $\begin{array}{l}\text { Reflexive - } \\
\text { Synergetic }\end{array}$ & $\begin{array}{l}\text { Target activity and development } \\
\text { Constructiveness of management activity }\end{array}$ & $\begin{array}{l}\text { The socially cautionary nature of management's mission to changes of } \\
\text { educational paradigm }\end{array}$ \\
\hline 6. & $\begin{array}{l}\text { Synergetic - } \\
\text { Reflexive }\end{array}$ & $\begin{array}{l}\text { Constructiveness of management activity } \\
\text { Target activity and development }\end{array}$ & $\begin{array}{l}\text { Cooperation of influence of stakeholder groups on management } \\
\text { strategy of changes }\end{array}$ \\
\hline 7. & $\begin{array}{l}\text { Reflexive - } \\
\text { Competency }\end{array}$ & $\begin{array}{l}\text { Target activity and development } \\
\text { Social responsibility of management activity }\end{array}$ & $\begin{array}{l}\text { Expert and evaluative monitoring of the management mission of } \\
\text { influence on changes of educational paradigm }\end{array}$ \\
\hline 8. & $\begin{array}{l}\text { Competence - } \\
\text { Reflexive }\end{array}$ & $\begin{array}{l}\text { Social responsibility of management activity } \\
\text { Target activity and development }\end{array}$ & $\begin{array}{l}\text { Personalization of resources of management strategy of changes of } \\
\text { educational paradigm }\end{array}$ \\
\hline 9. & $\begin{array}{l}\text { Axiological - } \\
\text { Synergetic }\end{array}$ & $\begin{array}{l}\text { Moral purpose of management } \\
\text { Constructiveness of management activity }\end{array}$ & $\begin{array}{l}\text { Adaptability of educational paradigm's values in the period of social } \\
\text { and transformer turbulence }\end{array}$ \\
\hline 10. & $\begin{array}{l}\text { Synergetic - } \\
\text { Axiological }\end{array}$ & $\begin{array}{l}\text { Constructiveness of management activity } \\
\text { Moral purpose of management }\end{array}$ & $\begin{array}{l}\text { Management mission of generation of humane technologies of "soft } \\
\text { power" as for subjects of educational paradigm }\end{array}$ \\
\hline 11. & $\begin{array}{l}\text { Axiological - } \\
\text { Competency }\end{array}$ & $\begin{array}{l}\text { Moral purpose of management. } \\
\text { Social responsibility of management activity }\end{array}$ & $\begin{array}{l}\text { Approval the human-centric strategy of management as for the } \\
\text { development of resources of educational paradigm subjects }\end{array}$ \\
\hline 12. & $\begin{array}{l}\text { Competency - } \\
\text { Axiological }\end{array}$ & $\begin{array}{l}\text { Social responsibility of management activity } \\
\text { Moral purpose of management }\end{array}$ & $\begin{array}{l}\text { The development of professional resources and value orientation of } \\
\text { educational paradigm subjects }\end{array}$ \\
\hline 13. & $\begin{array}{l}\text { Axiological - } \\
\text { Guiding }\end{array}$ & $\begin{array}{l}\text { Moral purpose of management } \\
\text { Generating and implementation of changes }\end{array}$ & $\begin{array}{l}\text { Provision of the priority of mental values and standards in } \\
\text { management of the educational paradigm }\end{array}$ \\
\hline 14. & $\begin{array}{l}\text { Duiding - } \\
\text { Axiological } \\
\end{array}$ & $\begin{array}{l}\text { Generating and implementation of changes } \\
\text { Moral purpose of management }\end{array}$ & $\begin{array}{l}\text { Managerial motivation of "agents of changes" as for their } \\
\text { humanistic mission in the educational paradigm }\end{array}$ \\
\hline 15. & $\begin{array}{l}\text { Synergetic - } \\
\text { Guiding }\end{array}$ & $\begin{array}{l}\text { Constructiveness of management activity } \\
\text { Generation and implementation of changes }\end{array}$ & $\begin{array}{l}\text { Provision of continuum succession of ideas of changes of the national } \\
\text { system of the educational paradigm }\end{array}$ \\
\hline 16. & $\begin{array}{l}\text { Guiding - } \\
\text { Synergetic }\end{array}$ & $\begin{array}{l}\text { Generation and implementation of changes } \\
\text { Constructiveness of management activity }\end{array}$ & $\begin{array}{l}\text { Adoption of non-paradigmatic and irrational ideas of changes in } \\
\text { methodologies, technologies of the educational paradigm and its } \\
\text { structure }\end{array}$ \\
\hline 17. & $\begin{array}{l}\text { Synergetic - } \\
\text { Competency }\end{array}$ & $\begin{array}{l}\text { Constructiveness of management activity } \\
\text { Social responsibility of management activity }\end{array}$ & $\begin{array}{l}\text { Forming of complex organizational systems of management of the } \\
\text { educational paradigm }\end{array}$ \\
\hline 18. & $\begin{array}{l}\text { Competency - } \\
\text { Synergetic } \\
\end{array}$ & $\begin{array}{l}\text { Social responsibility of management activity } \\
\text { Constructiveness of management activity }\end{array}$ & $\begin{array}{l}\text { The development of management competences by complex synergetic } \\
\text { systems in the educational paradigm }\end{array}$ \\
\hline 19. & $\begin{array}{l}\text { Competency - } \\
\text { Guiding }\end{array}$ & $\begin{array}{l}\text { Social responsibility of management activity } \\
\text { Generation and implementation of changes }\end{array}$ & $\begin{array}{l}\text { The effective activity in the development of systems of } \\
\text { organizational and managerial engineering }\end{array}$ \\
\hline 20. & $\begin{array}{l}\text { Guiding - } \\
\text { Competency }\end{array}$ & $\begin{array}{l}\text { Generation and implementation of changes } \\
\text { Social responsibility of management activity }\end{array}$ & $\begin{array}{l}\text { The implementation of definite levels of the effective guiding activity } \\
\text { as for the development of the educational paradigm }\end{array}$ \\
\hline
\end{tabular}


minets.

On the basis of the analysis we propose (Pearson's formula) the following ranking of scientific paradigm of the educational space according to the level of their coordinated existence and conflicts.

Coordinated existence: 1) axiological paradigm - 0.9; 2) reflexive paradigm -0.7 ; 3) guiding paradigm -0.7 ; 4) competence paradigm $-0.6 ; 5)$ synergetic paradigm -0.5 .

Accordingly, conflict: 1) synergetic paradigm - 0.5; 2) Competence paradigm $-0.4 ; 3$ ) reflective paradigm -0.3 ; 4) guiding paradigm $-0.3 ; 5)$ axiological paradigm -0.1 .

We have defined the natural process of the constant flow of professional interests of scientific and pedagogical staff from the resources of one paradigm to another. It was recorded that the absolute majority of managers perceive the fact of real coexisting of scientific paradigms defined by us in the space of higher education of Ukraine as a pragmatic reality and they are not oriented towards attempts to replace or to remove them in their own research studies.

We made an attempt of mathematically grounding of coordinated non-conflict correlation of transversal directions of paradigms of the educational space defined by us. 92 heads of educational establishments took part in the experiment (work experience of at least 5 years) and 90 graduate masters in specialty 073 Management (Management of Educational Establishments). The first category of respondents revealed the initial and sufficient level of organization of the scientific work; graduate masters are at initial level of understanding the problem of polyparadigmality and they are full of romantic ideas at the level "high po". According to Mana Whitney's criterion we accept the null hypothesis according to which in the management of polyparadigmal educational space (schools, lyceums, universities) the main expectations of the phenomenon of transversality connected with its humanization and value-semantic adaptation to social fluctuations and turbulence; problems of insufficient social responsibility for results of transversal character of functioning of the polyparadigmal educational space; enhancing the creative potential of education subjects and tolerance in evaluating the positions of other paradigmal groups.

The main indicators for calculating were paradigm content components of Table 1 (Table 2)

The results confirmed our assumption (null hypothesis) with high probability, the difference in levels of defined samples is insignificant and is within the predictability.

Conclusions. We do not absolutize the results of our research. They may change under certain conditions: changes in social order (requirements) to the results of educational management; the authors' unique or guiding understanding of resources of reverse paradigm by individual manager or institution; correlation influence of scientific and pedagogical and management research studies of the globalized educational space; situational need in the management of education; phenomenal or creative thought activity of subjects of education. It was defined that the idea of transversality in educational management is now at "academic" level and has not become methodological or technological basis for the level of practical management of education yet. The transversal character of the polyparadigmal educational environment is its implicit methodology which not only makes the existence of selected scientific concepts possible but also enriches this environment with new "composite" forms. There occurs a process of partial transformation of each paradigm adapting them to imperative and situational changes of the educational space. This creates conditions under which the emergent factors and new phenomena in the development of the educational paradigm appear.

Introduced by us, the concept "polyparadigmal educational space" will become the object of scientific discourse. The scheme of the authors' technologies of the analysis of emergent zones in transversal interaction of the educational
The paradigm content components

\begin{tabular}{|c|c|c|c|c|}
\hline No. & $\begin{array}{c}\text { Components of transversal } \\
\text { interaction of educational space } \\
\text { paradigms }\end{array}$ & masters & $\begin{array}{c}\text { Heads } \\
\text { (managers) }\end{array}$ & rank \\
\hline 1. & $\begin{array}{l}\text { The evaluation of values with } \\
\text { the purpose of their stabilization } \\
\text { or managed transformation }\end{array}$ & 90 & 86 & 1.5 \\
\hline 2. & $\begin{array}{l}\text { Adaptability of values in the } \\
\text { period of social and transformer } \\
\text { turbulence }\end{array}$ & 85 & 92 & 1.5 \\
\hline 3. & $\begin{array}{l}\text { Irrational nature of changes in } \\
\text { the structure and content of the } \\
\text { educational space }(E S)\end{array}$ & 80 & 92 & 3 \\
\hline 4. & $\begin{array}{l}\text { Phenomenal character of solving } \\
\text { the mission of changes of ES }\end{array}$ & 80 & 92 & 4 \\
\hline 5. & $\begin{array}{l}\text { Expert-evaluative status of } \\
\text { actions of influence }\end{array}$ & 75 & 50 & 5.5 \\
\hline 6. & $\begin{array}{l}\text { Moral and cautionary nature of } \\
\text { the mission of influence on the } \\
\text { educational space }\end{array}$ & 78 & 50 & 5.5 \\
\hline 7. & $\begin{array}{l}\text { Non-entropy nature of the } \\
\text { structural changes of the } \\
\text { educational space }\end{array}$ & 71 & 58 & 7 \\
\hline 8. & $\begin{array}{l}\text { Creation of new conditions and } \\
\text { organizational forms of the } \\
\text { educational space }\end{array}$ & 70 & 86 & 8 \\
\hline 9. & $\begin{array}{l}\text { Providing the polymorphism of } \\
\text { changes of the educational space }\end{array}$ & 82 & 80 & 9 \\
\hline 10. & $\begin{array}{l}\text { Strengthening of social } \\
\text { responsibility of management of } \\
\text { the educational space }\end{array}$ & 90 & 92 & 10 \\
\hline
\end{tabular}

paradigm is already directed to the technological arsenal of education creative managers. For three years, the successful approbation of our ideas has been carried out in the educational process of training of educational managers according to specialty "Management of Educational Establishment". The internal logic of paradigmality is briefly disclosed in the authors' scheme of transversal interaction of the domestic polyparadigmal educational space. The determined content components of transversal interaction of educational space paradigms can be recommended for predictive research activity of managers of educational establishments with the aim of defining the real emergent zones and acquiring competencies of "guides of changes".

We see the prospects of the further work in the development of research technological models of defining dynamic connections of scientific paradigm of the educational space, with possibility of their adaptation to individual characteristics and resources of the educational subjects (managers and guides).

\section{References.}

1. Horbunova, L. S. (2012). Thinking in the world of plurality: project of transversal mind by V. Welsh. Philosophy of education: scientific journal, 1-2(11), 92-110.

2. Novikova, O. V. (2008). The problem of the development of creative thinking in the system of Edward de Bono. Retrieved from http://www.disser.com.ua/content/350926.html\#download. 3. Cedefop (2008). European Training Thesaurus. Retrieved from http://www.cedefop.europa.eu/EN/Files/3049 en.pdf. 4. Sobol, N. (2016). Transversal skills and abilities in the structure og professional competence of teacher. Bulletin of the National Academy of State Border Guard Service of Ukraine. Series: Pedagogy, (4). Retrieved from http://www.nbuv.gov.ua/ UJRN/Vnadped_2016_4_13. 
5. Voloshyna, L.O., Leko, B.A., \& Kushnir, L.D. (2016). Lateral thinking as an important component of clinical thinking of future doctors. Medychna osvita, (1), 11-14.

6. Dmytryev, S. V., Neverkovych, S. D., Bystrytska, E.V., \& Voronyn, D. I. (2014). Semantic space of "alive motions" in the sphere of language consciousness a s self-conscious of man as a creative personality. World of psychology, (3), 173-186.

7. Starokozhko, O. M. (2017). Strategies of polyparadigmality of educational space. Visnyk Luhanskoho Natsionalnoho Universytetu imeni Tarasa Shevchenka, 8(313), 223-230.

8. Vitvitska, S. S. (2015). System-synergetic approach to pedagogical training of future masters of education. Professional pedagogical education: system research: monography. In edit. by O.A. Dubaseniuk (Ed.), (pp. 92-108). Zhytomyr: Publ. House ZhDU named after I. Franko, 92-108.

9. Bohdanov, I. T., Kryzhko, V.V., \& Lysakov, S.V. (2017). Guidance in education. From idea to eternity: monography. Bohdanov, I. T. (Ed.). Kyiv: Education of Ukraine.

10. Bohdanov, I., Lysakov, S., Nemchenko, S., \& Kryzhko, V. (2018). The of guiding in higher education management. Vyshcha osvita Ukrainy, (1), 11-20.

11. Bogdanov, I.T., Lysakov, S. V., \& Kryzhko, V.V. (2018). The guidance as a modern frame of management by changes in education. Virtus: Scientific Journal, (24), 56-63.

\section{Трансверсальний характер поліпарадигмального освітнього простору}

\section{О. М. Старокожко, В. В. Крижко, В. І. Жигірь}

Бердянський державний педагогічний університет, м. Бердянськ, Україна, e-mail: starokogko@ukr.net

Мета. Дослідження основних трансверсальних характеристик поліпарадигмального освітнього простору.

Методика. Науковий дискурс вітчизняних і зарубіжних науковців щодо обраної проблематики; історіографічний метод континууму наукових концептів освітнього простору; технології рефлексивного аналізу здобутків наукової спільноти та власного досвіду в галузі управління соціальним середовищем і його структурними системами; моделювання процесів трансверсальних зв'язків; методи математичного аналізу для встановлення реальних закономірностей трансверсальної кореляції чи конфліктності концептів поліпарадигмального освітнього середовища.

Результати. Нами встановлено, що трансверсальний характер поліпарадигмального освітнього середовища $€$ його імпліцитною методологією, яка збагачує його новими «композитними» формами. При цьому створюються умови, за яких виникають емерджентні фактори й нові феномени в розвитку освітніх парадигм. Розроблена схема авторської технології аналізу емерджентних зон трансверсальної взаємодії освітніх парадигм. Внутрішня логіка поліпарадигмальності стисло розкрита в авторській схемі трансверсальної взаємодії вітчизняного поліпарадигмального освітнього простору. Визначені змістовні компоненти трансверсальної взаємодії парадигм освітнього простору. Апробація результатів упродовж трьох років здійснюється в освітньому процесі підготовки менеджерів освіти зі спеціальності «Управління навчальним закладом».

Наукова новизна. Уперше запропоновано й запроваджено до наукового вжитку поняття «поліпарадигмальний освітній простір»; визначені чинники дуальної трансверсальної взаємодії освітніх парадигм і розроблена схема трансверсальної взаємодії освітніх парадигм.

Практична значимість. Використання отриманих результатів започатковує науковий дискурс із проблеми методології поліпарадигмальності та трансверсальності освітнього простору. Розроблені технологічні схеми й моделі можуть бути використані в подальших наукових дослідженнях і навчальному процесі з підготовки менеджерів освіти.

Ключові слова: поліпарадигмальний освітній простір, трансверсальний розум, трансверсальні навички, рефлексивна парадигма, компетентнісна парадигма, синергетична парадигма, аксіологічна парадигма, провідницька парадигма

\section{Трансверсальный характер полипарадигмального образовательного пространства}

\author{
О. Н. Старокожкко, В. В. Крижкко, В. И. Жигирь
}

Бердянский государственный педагогический университет, г. Бердянск, Украина, e-mail: starokogko@ukr.net

Цель. Исследование основных трансверсальных характеристик полипарадигмального образовательного пространства.

Методика. Научный дискурс отечественных и зарубежных ученых по выбранной проблематике; историографический метод континуума научных концептов образовательного пространства; технологии рефлексивного анализа достижений научного сообщества и собственного опыта в области управления социальной средой и его структурными системами; моделирование процессов трансверсальных связей; методы математического анализа для установления реальных закономерностей трансверсальной корреляции или конфликтности концептов полипарадигмальной образовательной среды.

Результаты. Нами определено, что трансверсальный характер полипарадигмальной образовательной среды является его имплицитной методологией, которая обогащает его новыми «композитными» формами. При этом создаются условия, при которых возникают эмерджентные факторы и новые феномены в развитии образовательных парадигм. Разработана схема авторской технологии анализа эмерджентных зон трансверсального взаимодействия образовательных парадигм. Внутренняя логика полипарадигмальности кратко раскрыта в авторской схеме трансверсального взаимодействия отечественного полипарадигмального образовательного пространства. Определены содержательные компоненты трансверсального взаимодействия парадигм образовательного пространства. Апробация результатов в течение трех лет осуществляется в образовательном процессе подготовки менеджеров образования по специальности «Управление учебным заведением».

Научная новизна. Впервые предложено и внедрено в научный дискурс понятие «полипарадигмальное образовательное пространство»; определены факторы дуального трансверсального взаимодействия образовательных парадигм и разработана схема трансверсального взаимодействия образовательных парадигм.

Практическая значимость. Использование полученных результатов начинает научный дискурс по проблеме методологии полипарадигмальности и трансверсальности образовательного пространства. Разработанные технологическая схема и модель могут быть использованы в дальнейших научных исследованиях и учебном процессе по подготовке менеджеров образования.

Ключевые слова: полипарадигмальное образовательное пространство, трансверсальный разум, трансверсальные навыки, рефлексивная парадигма, компетентностная парадигма, синергетическая парадигма, аксиологическая парадигма, проводническая парадигма

Recommended for publication by Pavlo Zakharchenko, Doctor of Economic Sciences. The manuscript was submitted 14.10.19. 